\title{
31. POTASSIUM-ARGON AGE OF A BASALT FROM HOLE 319A, DSDP LEG 34
}

\author{
Marvin A. Lanphere and G. Brent Dalrymple, U.S. Geological Survey, Menlo Park, California
}

\begin{abstract}
A potassium-argon age of $\geq 13.0 \pm 1.5$ m.y. was measured on relatively fresh basalt from Hole $319 \mathrm{~A}$. This age should be close to, if not equal to, the age of crystallization, and it agrees, within analytical uncertainty, with the age of $15 \pm 1 \mathrm{~m} . \mathrm{y}$. for the Orbulina datum that occurs a few meters above the sediment-basalt contact.
\end{abstract}

\section{INTRODUCTION}

Site 319 is located in the Bauer Deep, a depression between the active East Pacific Rise to the west and the extinct Galapagos Rise to the east. Hole 319 penetrated a sequence of sediments 110 meters thick and 6.5 meters of relatively fresh basalt. A second hole, Hole 319A, was drilled at the site with the objective of continuously coring as much basalt as possible. In Hole 319A, 39 meters of basalt were cored representing at least 6 , possibly 11 , cooling units as much as 15.6 meters thick.

Samples of basalt from Core 3, Section 5, Hole 319A were used in this study. Whole rock $\mathrm{K}$-Ar ages were measured on a $2.2-\mathrm{cm}$-diameter transverse core (drilled at right angles to the DSDP core) sampled at $21-24 \mathrm{~cm}$, and $\mathrm{K}-\mathrm{Ar}$ ages were measured on plagioclase phenocrysts separated from a transverse core sampled at 19-21 $\mathrm{cm}$. These samples are approximately 25 meters below the sediment-basalt contact. The basalt at $21-24 \mathrm{~cm}$ is a fine-grained holocrystalline rock that consists primarily of plagioclase, clinopyroxene, and opaque minerals. Plagioclase and pyroxene phenocrysts are as long as 2 $\mathrm{mm}$ but most are smaller. No glass was observed in thin section. Clots of very fine-grained clay mineral (smectite?) alteration are scattered through the rock; these altered clots make up about $3 \%$ of the rock. In general, the basalt is quite fresh and yielded, at least, a reliable minimum age. Because of the small amount of alteration, we estimate that the whole rock K-Ar age should be close to or equal to the age of crystallization.

Major and large ion lithophile element concentrations and strontium isotope measurements indicate that the basalts in Hole 319A are typical abyssal tholeiites similar to those that originate at mid-ocean ridges (Hart, 1974).

\section{RESULTS AND DISCUSSION}

The K-Ar ages and analytical data are given in Table 1. Argon measurements were made using techniques described previously (Dalrymple and Lanphere, 1969) and a 15-cm-radius rare-gas mass spectrometer. Potassium measurements on basalt were made by flame photometry using the lithium metaborate fusion technique (Ingamells, 1970). Potassium measurements on plagioclase were made by isotope dilution using a mixed ${ }^{40} \mathrm{~K}$ ${ }^{41} \mathrm{~K}$ tracer and a $30-\mathrm{cm}$-radius solid-source mass spectrometer.
The mean age for the basalt sample (Table 1) was calculated by weighting each measurement by the inverse of its estimated variance. The plagioclase measurements, unfortunately, did not yield any useful age information because the corrections for nonradiogenic ${ }^{40} \mathrm{Ar}$ are so large that the analytical uncertainties in the calculated ages also are very large (Table 1). The same problem arose in age measurements on plagioclase from Hole 317A, DSDP Leg 33 (Lanphere and Dalrymple, in press).

The $13.0 \pm 1.5$-m.y. age for the basalt sample (Table 1) is considered a reliable minimum age for extrusion of the sequence of basalts penetrated in Hole 319A. Only a single sediment sample was recovered from Hole 319A, and the best paleontologic data on the age of the basalt basement were obtained from Hole 319 at the same site. In Hole 319 a 110 -meter-thick sequence of sediments ranging in age from Quaternary to early Miocene was drilled before basalt was reached (Part I, this volume). The oldest fossils recovered from the core catcher of Core 12 (the $5.5 \mathrm{~m}$ of sediment above basalt basement) are planktonic foraminfers of Zone N.8 (Chapter 3, this volume). The N.8/N.9 boundary was placed at the top of Core 12; that is, about 5.5 meters above the contact with basalt.

The Orbulina datum (the first evolutionary appearance of the genus) defines the base of Zone N.9 (Blow, 1969). A number of radiometric ages relevant to the $\mathrm{Or}$ bulina datum that can be compared to the K-Ar age of basalt in Hole 319A have been reported in other studies. Van Couvering and Berggren (in press) reviewed the Neogene time scale and suggested an approximate age of $15 \mathrm{~m} . \mathrm{y}$. for the Orbulina datum. Page and McDougall (1970) measured K-Ar ages ranging from 12.5 to 15 m.y. on volcanic rocks in New Guinea that overlie, and in places interfinger with, sedimentary rocks containing a fauna approximating planktonic foraminiferal zones N.9 to N.12. From their data, Page and McDougall estimate an age of 14 to 15 m.y. for the Orbulina datum in New Guinea. Ikebe et al. (1972) estimate an age of 15 \pm 1 m.y. for the Orbulina datum in Japan.

Ages of $15 \pm 1$ m.y. for the Orbulina datum and 13.0 \pm 1.5 m.y. for basalt from Hole 319A agree within experimental uncertainties and thus are consistent with the stratigraphy at Site 319. Corliss et al. (1974) reported an age of $8 \pm 2 \mathrm{~m} . \mathrm{y}$. for basalt from Hole 319A; this is discordant with the age of the sediments. Because of the 
TABLE 1

Potassium-Argon Ages and Analytical Data, Hole 319A, DSDP Leg 34

\begin{tabular}{|c|c|c|c|c|c|}
\hline $\begin{array}{l}\text { Sample } \\
\text { (Interval } \\
\text { in } \mathrm{cm} \text { ) }\end{array}$ & Material & $\begin{array}{l}\mathrm{K}_{2} \mathrm{O}^{\mathrm{a}} \\
(\mathrm{wt} \%)\end{array}$ & $\begin{array}{l}{ }^{40} \mathrm{Ar}_{\mathrm{rad}} \\
(\mathrm{mol} / \mathrm{g})\end{array}$ & $\frac{100^{40} \mathrm{Ar}_{\mathrm{rad}}}{40 \mathrm{Ar}_{\text {total }}}$ & $\begin{array}{c}\text { Calculated Age } \\
\left(10^{6} \mathrm{yr}\right)\end{array}$ \\
\hline $3-5,19-21$ & Basalt & $0.118(4)$ & $\begin{array}{l}2.287 \times 10^{-12} \\
2.274\end{array}$ & $\begin{array}{l}5.1 \\
7.2\end{array}$ & $13.0 \pm 1.5$ \\
\hline $3-5,21-24$ & $\begin{array}{c}\text { Plagioclase } \\
(105-149 \mu \mathrm{m})\end{array}$ & $0.0394(1)$ & 1.858 & 0.9 & $32.5 \pm 47.4$ \\
\hline $3-5,21-24$ & $\begin{array}{c}\text { Plagioclase } \\
(63-105 \mu \mathrm{m})\end{array}$ & 0.0501 & 1.358 & 0.8 & $18.2 \pm 26.7$ \\
\hline
\end{tabular}

\footnotetext{
${ }^{a}$ Mean values. The number in parentheses is the number of measurements. Isotope dilution values shown in italics. Other measurements were made by flame photometry.

$\mathrm{b}_{\lambda_{\epsilon}}=0.585 \times 10^{-10} \mathrm{yr}^{-1}, \lambda_{\beta}=4.72 \times 10^{-10} \mathrm{yr}^{-1},{ }^{40} \mathrm{~K} / \mathrm{K}_{\text {total }}=1.19 \times 10^{-4} \mathrm{~mol} / \mathrm{mol}$.

The \pm figures assigned each age are estimates of analytical precision at the $68 \%$ confidence level (Cox and Dalrymple, 1967).
}

discordant age relations, these authors suggested that the basalts either represented a younger intrusion into the sedimentary sequence or that potassium had been added during weathering. On the basis of our results, we suggest that the age reported by Corliss et al. (1974) may not represent a geologic event but instead reflects loss of radiogenic ${ }^{40} \mathrm{Ar}$, or perhaps addition of potassium, as a result of alteration.

\section{ACKNOWLEDGMENTS}

We thank the following for their laboratory assistance: R.D. Dockter for mineral separations, J.Y. Saburomaru for sample preparation, L.B. Schlocker and A.L. Berry for potassium measurements, and S.J. Kover, B.M. Myers, and J.C. Von Essen for argon extraction, mass analyses, and data reduction. We also thank R.J. Fleck and R.Z. Poore for their helpful comments upon reviewing the manuscript.

\section{REFERENCES}

Blow, W.H., 1969. Late middle Eocene to Recent planktonic foraminiferal biostratigraphy. In Bronniman, P., and Renz, H.R. (Eds., Internatl. Conf. Plankt. Microfossils, 1st Proc., Geneva, 1967, v. 1, p. 199.

Corliss, J.G., Dymond, J., Dasch, E.J., and Field, C.W., 1974. Major and trace element geochemistry, age, and isotopic studies of Leg 34 basalts (abs.): Geol. Soc. Am. Abstracts with Programs, v. 6, p. 694.

Cox, A. and Dalrymple, G.B., 1967. Statistical analysis of geomagnetic reversal data and the precision of potassiumargon dating: J. Geophys. Res., v. 72, p. 2603.

Dalrymple, G.B. and Lanphere, M.A., 1969. Potassium-argon dating; San Francisco (Freeman).

Hart, S.R., 1974. LIL-element geochemistry, Leg 34 basalts (abs.): Geol. Soc. Am. Abstracts with Programs, v. 6, p. 780.

Ikebe, N., Takayanagi, Y., Chiji, M., and Chinzei, K., 1972. Neogene biostratigraphy and radiometric time scale of Japan: an attempt at intercontinental correlation: Pacific Geol., v. 4, p. 39.

Ingamells, C.O., 1970. Lithium metaborate flux in silicate analysis: Anal. Chim. Acta, v. 52, p. 323.

Lanphere, M.A. and Dalrymple, G.B., in press. K-Ar ages of basalts from DSDP Leg 33: Sites 315 (Line Islands) and 317 (Manihiki Plateau). In Jackson, D.E., Schlanger, S.O., et al., Initial Reports of the Deep Sea Drilling Project, Volume 33: Washington (U.S. Government Printing Office).

Page, R.W. and McDougall, I., 1970. Potassium-argon dating of the Tertiary $f_{1-2}$ stage in New Guinea and its bearing on the geological time scale: Am. J. Sci., v. 269, p. 321.

Van Couvering, J.A. and Berggren, W.A., in press. Biostratigraphical basis of the Neogene. In Kauffmann, E.G. and Hazel, J.E. (Eds.), Concepts in biostratigraphy: Lawrence, Kansas (Paleontological Soc.). 